Helgoländer wiss. Meeresunters. 20, 455-463 (1970)

\title{
The development of a maricultural technology for the penaeid shrimps of the Gulf and Caribbean Region
}

\author{
H. H. WEBBER \\ Groton Associates, Inc.; Groton, Massachusetts, USA
}

KURZFASSUNG: Die Entwicklung einer Meereskultur-Technologie für die penaeiden Garnelen des Golfs und der karibischen Region. Der zunehmende Bedarf an Garnelen für Speisezwecke hat in den USA zu beträchtlichen Investitionen geführt mit dem Ziel, rentable Verfahren für eine umfangreiche Zucht von Penaeiden zu entwickeln. Als erfolgreich hat sich die Züchtung von den im Golf von Mexiko auftretenden Peneus duorarum, $P$. setiferus und $P$. aztecus erwiesen, deren Fortpflanzungsbiologie und Larvenkultur beschrieben wird. Die Möglichkeiten für eine Intensivkultur der Decapodite dieser Arten in Teichen und deren Aufzudt bis zum adulten Stadium in abgeschlossenen Meeresbuchten werden unter Berücksichtigung der Futteransprüche und Fangmethoden diskutiert.

\section{INTRODUCTION}

Of the 162 species of shrimps and prawns of economic value listed by HoLtHuis \& Rosa (1965) one-half, 81 species, belong to the family Penaeida which contains all but two, Pandalus borealis and Crangon crangon, of those 24 species which are noted as being of major commercial significance. Of these, most are in the genus Penaeus, and only $P$. japonicus, $P$. monodon and $P$. indicus are recorded by the authors as the penaeids being cultivated in prawn ponds. Since the publication of this listing, several Gulf und Caribbean species of penaeids have been studied in the United States as candidate organisms for both intensive and extensive cultural systems.

The commercial shrimp trawling industry has realized considerable growth in the past two decades, in large part, as a consequence of an apparently insatiable market demand for crustacean seafoods in the developed markets of Europe, North America and Japan. This demand has supported and justified a continuing search for new, previously unexploited wild populations of shrimps and prawns in the world's oceans, as well as a commensurate effort to improve fishing efficiency by the design and development of improved detection methods and catching gear. However, the significant success in increasing the catch year after year has not kept up with the market demand, and consequently the selling price for shrimp in the developed world has responded with mounting annual increases. In the United States, shrimp sold at $\$ 1.05$ at retail in 1960 , whereas by 1968 the mean selling price was $\$ 1.35$ 
per pound. The United States demand has increased at a rate of approximately $6 \%$ per year, far exceeding the rate of population growth, so that the per capita consumption has increased from 0.87 pounds to 1.41 pounds over the last decade. Over the same period the native shrimping grounds have been unable to sustain commensurate production. Therefore, the supply has had to be supplemented by imports which in 1958 amounted to about $40 \%$ of the 213 million pounds consumed whereas by 1968 imports were $54 \%$ of 389 million pounds consumed (FISHERIEs of the United States 1968).

Since a large portion of the world shrimp catch comes from tropical waters bordering on the shores of the developing countries of Latin America, Africa and Asia, and the major markets are for the most part in the developed countries, an important contribution to a favorable foreign exchange balance is achieved by many developing countries in the tropics.

Nonetheless, as long as the high demand and selling price for shrimps and prawns continues to increase, there will be a strong economic motivation to develop a supplemental source to the trawler-caught stocks. A maricultural system for rearing these animals in large numbers may provide a mechanism to accomplish this end.

\section{RESULTS AND DISCUSSION}

By the application of sound animal husbandry practices, we may expect to achieve an assurance for a reasonably constant year round supply, thus freeing the market from the vicissitudes of a hunted resource. The achievement of improved breeds by genetic manipulation and cultural practices will contribute to quality improvement tailored to product preference in the market. The integration of pond harvesting techniques with processing will provide further assurance of the retention of initial high quality (WEBBER 1968).

\section{Larviculture in the Far East}

The culture of shrimps and prawns in the Far East is an ancient art which is essentially a pastoral practice, capturing fry or juveniles in the estuarine or shallow coastal waters and introducing them into ponds formed by earthen dikeworks. Such is the practice in the Philippines with the "sugpo" Penaeus monodon (BorJa \& RASALAN 1969). Alternatively stocks of the young are captured as a natural recruitment in tidal currents which carry the fry through gates into ponds, as is the practice in Singapore, Indonesia, and elsewhere in Southeast Asia (Kow 1969).

For the most part Asian methods depend on the natural productivity generated in the ponds as the sole feed resource, with little or no fertilization. However, the shrimp flourish on a rich and nutritious growth of microscopic plant and animal organisms, called "lablab" by the Filipinos, which develops on the natural fertility in the pond bottoms. Such shrimp farming, or I prefer to call it ranching, yields in the order of $1250 \mathrm{~kg}$ per ha (or one-half ton per acre) with a local wholesale value of $\$ 600$ U.S. per acre per year according to RYTHER \& BARDACH (1968). 


\section{Larviculture in Japan}

Environmental controls are primitive, and predators and competitors are frequently introduced with the stock, resulting in considerable inefficiencies in production and relatively low yields per unit area of ponds. In Japan where the market demand for shrimps is very high, and where the near and distant water fisheries have been unable to meet these requirements, a partially successful effort has been mounted by government subsidized private industry to develop a more sophisticated maricultural technology for the rearing of Penaeus japonicus. This work was led by Fujinaga and his associates (1942).

As is the case with most of the species of the genus Penaeus, the life history of japonicus starts with spawning in deep off-shore waters, followed by a relatively short, approximately three weeks, larval-development period. During larval development the young are carried or migrate shoreward and enter less saline waters (10-30 ppt.) where they ordinarily spend the juvenile growth period in the nutrient rich waters close inshore or inside the estuaries. Gonadal development is apparently initiated in the lower salinity waters, but sexual maturity and spawning are not realized until the shrimp have migrated offshore again into full salinity and deeper waters. Eggs are cast at depths up to 30 fathoms and are fertilized from sperm receptacles which have been attached to the underside of the female during mating. Fertilized eggs hatch within a day; hatching is followed by a series of larval stages which we will discuss in a moment. The life cycle is completed within about one year (IDYLL \& SisSON 1965).

The shrimp culture technology developed by FujINAGA (1963) is based upon such observations. He starts with a gravid, or ripe female which is procured from the trawler catch of commercial fishermen. These gravid females are brought into the hatchery and retained in tanks where spawning occurs, usually within the first 12 to $24 \mathrm{~h}$. The female may cast as many as 1 million eggs although frequently less than $1 / 4$ million may be spawned.

As soon as the eggs are released the mothers are removed to prevent them from foraging on the eggs. The eggs, which would ordinarily sink, are kept floating by compressed air agitation of the water, which is kept between $25.0^{\circ}$ and $31.1^{\circ} \mathrm{C}\left(77^{\circ}\right.$ and $88^{\circ} \mathrm{F}$ ). This hatching period lasts between 13 and $14 \mathrm{~h}$ before the nauplii hatch from the egg.

A larval population density of about 1,000 per 1 ( 10,000 per gallon) is maintained. After $36 \mathrm{~h}$ and 6 molts during which time the larvae exists on the yolk substances of the egg, the nauplius changes to the protozoeal stage. There are three zoeal stages when phytoplankton feed is provided, for which diatoms such as Skeletonema costatum or Cyclotella nana are cultured. The diatom is kept suspended by air agitation in order to make it readily available to the shrimp. During the next larval stages, the mysis, the diatom is supplemented with animal protein source in the form of zooplankton such as oyster larvae, brine-shrimp (Artemia salina nauplii), copepods or rotifers. Each of the mysis stages lasts only one day following which the shrimp enters a postlarval period. At this stage it is important to keep an abundant supply of food available at all times to reduce cannibalism. The Japanese system employs 
ground mollusc meats as the primary feed supplement. After about 10 days of postlarval life in the hatchery tanks the shrimp are moved to concrete outdoor rearing ponds about 2 feet deep. These ponds have a double bottom providing a means of aerating the sand at the bottom in which they burrow during the daylight hours; the shrimp are thus kept feeding and their bottom environment is well oxygenated.

After 10 to 20 days during which they are fed the meats of the short neck clam (Tapes japonica), the shrimp have attained a length of $180 \mathrm{~mm}(3 / 4 \mathrm{inch})$, and are moved to finishing ponds which are about 4 hectares $(10$ acres) in area. Some are sold for stocking neighboring shrimp "farms" which do not operate hatcheries. The shrimp are harvested by dragging a special net. They are dislodged from the bottom sand, in which they prefer to remain during most daylight hours, by jets of water just in front of the nets. This mechanism results in high yields at the rate 9,000 pounds of shrimp per acre in 10 months, on an experimental basis.

The Japanese spawning and larviculture techniques through to the production of postlarvae or small juveniles, have proven highly successful, and tens of millions of postlarvae can be producted at a cost of about 0.1 c U.S. each. However, the culture of juvenile-to-market size shrimp is still limited by the inability to feed the rapidly growing shrimp economically, since the reliance on minced clam meat is not likely to be a commercially viable practice. Along the shores of the Inland Sea of Japan, where many shrimp hatcheries are maintained with government subsidies, postlarvae are produced mainly for stocking managed embayments, with the expectation that stocking natural waters will make a significant contribution to the commercial trawler catch. This has not yet been proven to be a sound practice.

Whereas Japanese workers report success in closing the life cycle of Penaeus japonicus in captivity, there is still a total reliance on the capture of gravid females from the wild for a source of fertilized eggs. However, the ability to rear sequential generations of Penaeids makes it possible to undertake genetic improvement programs, which adds a major new dimension to shrimp culture. No report of Japanese genetic research on Penaeids has yet appeared in the literature.

\section{Larviculture in the United States}

The Japanese larviculture technology has been transposed to several laboratories on the Gulf Coast of the United States where, with some modifications, the techniques have proven successful with the Gulf of Mexico species: the pink shrimp Penaeus duorarum; the brown shrimp $P$. aztecus, and the white shrimp $P$. setiferus.

Shrimp mariculture in the United States is being explored in several government, university and industrial laboratories on the Gulf coast, but large-scale larviculture is most actively being investigated by Cook (1970) at the Bureau of Commercial Fisheries Laboratory in Galveston, Texas, Mryamura (1969) of Akima International Inc. at Panama City, Florida, and IDyLl et al. (1968) at the Institute of Marine and Atmospheric Sciences at the University of Miami, Miami, Florida. All three of the Gulf species have been successfully reared in the laboratory from gravid female to postlarvae and juvenile growth stages. Variations from Penaeus japonicus have been 
detected in the period and number of molts during the larval growth stages. Response to the feeding of various diatoms during the zoeal and subsequent stages, feeding rates and frequencies, stocking rates, temperature and salinity tolerances, water quality requirements, have all proven to be important factors in optimizing postlarval production, but time does not permit review of these details. It may be sufficient to note that postlarvae production of the pink and brown species is now very well in command, and several hatcheries now have the capability of producing millions of postlarvae per month. Penaeus setiferus, the white shrimp have proven to be equally amenable to management by similar hatchery techniques; but somewhat less research has been performed with this species, due to difficulties in procurement of gravid females.

\section{Intensive pond culture}

With the current availability of an abundance of post larval shrimps, the choice has to be made between an intensive cultural system where the animals are managed throughout their life cycle in confinement, and an extensive system in which the juveniles are turned out on the more or less open range to forage for themselves until they are subsequently caught by traditional trawling methods.

The design of culture ponds requires many considerations: the selection of suitable sites adjacent to high quality seawater and freshwater; a topography that enables economic mechanical or tidal pumping and a minimum of earth moving; clay soils with appropriate water-holding characteristics to obviate need and cost of lining ponds; as well as the many obvious site selection criteria relating to labor supply, power, transport, etc. The cultural system developed, will determine the economic pond size; but generally the larger the size of the pond that can be managed the lower the capital costs will be (WHEELER 1966).

Harvesting techniques will have a major influence on pond design and layout. The choice of a hard-packed clay bottom or a sandy bottom allowing for burrowing must be made in the light of certain behavioral characteristics of the species to be grown, the control over the formation of a reduction layer, harvesting methods utilizing a trawl or drain-down, or other technique. If the ponds are to be drained down to harvest, a catchbasin into which the shrimp will be carried by the receding waters must be incorporated into the design. If the ponds are to be located in a heavy rainfall area, a means of draining off freshwater inputs must be devised in order to ensure salinity control. Pond water depth and sunlight impingement, wind intensity and direction, as well as the reflection of the bottom will play a role determining water temperatures. Measures must be taken to guard against levee erosion due to wave action. Pond shape and orientation in relation to prevailing wind must be considered in order to gain maximum surface turbulence for aeration.

Probably the most important problem remaining to be solved in intensive culture, relates to supplying the nutritional requirements from post-larval to market size. This problem has been studied intensively by Oppenheimer (1968) at Florida State University at Tallahassee, and by Broom (1969) at the Marine Laboratory of the Louisiana Wildlife and Fisheries Commission at Grand Terre Island, Louisiana. 
Ground trash fish (striped mullet Mugil cepbalus), squid, and corn meal have been evaluted singly as rations to supplement the natural production occurring in the pond waters, with varying degrees of success. However, it has become apparent that a more complete ration can be formulated of such components as fish meal, fish solubles or stickwater; starch extenders such as corn, rice, or banana meals; and vitamin premix, in a pelletized form. Several commercial pelletized fish feeds varying in protein content and composition have been evaluated and found to encourage good growth with satisfactory conversion ratios. Feeding rates have been studied and it has been demonstrated that a rate of 5 to $10 \%$ of the body weight of shrimp in the ponds, fed daily, can yield economically satisfactory rates of growth better than $1 \mathrm{~mm}$ per day. The optimum feed rate is a function of the stage of growth, the composition of the feed and the environmental conditions maintained in the pond waters. Cannibalism has not been a problem in the experimental ponds when sufficient feed has been made available. Overfeeding, however, may become a serious problem when rates over 40 pounds per acre per day are used without supplemental aeration to compensate for the high BOD of the faeces.

According to Broom (1969), production of 809 pounds per acre in 80 days has been achieved in $1 / 4$ acre ponds. Stodking at the rate of 20,000 postlarvae per acre, white shrimp Penaeus setiferus, fed at the rate of $5 \%$ of their body weight daily increased their weight 10 times in 80 days, and averaged 28 shrimp to the pound, heads-on. Although stocking density had little effect on mortalities, the size of the shrimp harvested clearly reflects the density of stocking as well as the duration of the retention period. It has been demonstrated that the gain in pounds per acre per day is clearly higher at the feeding rate of $10 \%$ of body weight, but the conversion ratio also increases, thus requiring a careful benefit-cost analysis relating feed costs, conversion rate, retention time, to the market value, by size, of the shrimp harvested. Mortalities which can distort these results of course reflect many variables in the pond environment, thus pond management control measures are now being carefully studied and improved.

Our experimental ponds are monitored on a $24-\mathrm{h}$ basis for water temperature, salinity, $\mathrm{pH}$, and most importantly, oxygen tension. The BOD of unused feed, and the residue of phytoplankton blooms, is probably the most serious deterrent resulting in mass mortalities due to oxygen depletion. Reduced photosynthetic activity in the ponds during extended periods of cloudy weather, resulting in reduced dissolved oxygen, must be compensated for by mechanical aeration, or water exchange. Salinity control must be exercised to ensure that for the Gulf and Caribbean Penaeids, salinities are appropriate for the growing stages and generally may range from as low as $20 \mathrm{ppt}$ during juvenile growth periods on up to full salinity for adults. Generally however, salinity between 28 and $32 \mathrm{ppt}$ appears to give optimum results. Water temperatures falling between $24^{\circ}$ to $30^{\circ} \mathrm{C}$ encompass a suitable range, but generally cannot be realized through the winter months in the northern Gulf of Mexico. Consequently, in that region, a growing period of about 200 days is available for pond culture. In order to accomplish a 365-day yearly growing season, during which we hope to harvest 3 crops, we have had to move to lower latitudes, and have selected sites on the north coast of Honduras where the rich Caribbean 
waters of excellent quality support a large wild population of the Penaeids of the white, pink and brown species, thus providing a source of gravid females for support of a hatchery operation.

In order to realize the highest economic gain from the effort and to keep degradation to a minimum after harvesting, a processing plant is required to be integrated with the pond production sites. If this processing plant is to be fully mechanized, it will have to be of sufficient scale to justify the investment, and this in turn will determine the production capacity required of the ponds in order to keep these two components of the system in balance.

The indicated scale of production requires large volumes of feed. Thus the vertical integration of the enterprise includes a feed mill associated with the ponds, and the procurement of feed components from indigenous raw materials where feasible.

\section{Extensive embayment culture}

As noted above, an alternative to the confinement and rearing of juveniles in ponds, is a more extensive approach in which selected regions of natural waters, such as bays or coastal lagoons are densely stocked from a hatchery. The shrimp are allowed to grow on the natural productivity generated in the embayment, and are harvested by trawlers as any wild population would be.

Such an undertaking has been initiated in Florida on the northern coast of the Gulf of Mexico by an American firm with Japanese management, Akima International, Inc. Predator control is proposed to be accomplished by means of fencing off the mouth of a bay to exclude large, predaceous fish, crabs, etc. and treating the bay waters with rotenone or some other fugitive or short-lived fush poison, thus killing all predators trapped in the bay. After the poison has been dissipated, heavy stocking with postlarvae shrimp from a hatchery is proposed. Undomesticated populations of this sort, foraging on naturally occurring feeds, and subjected to the many vagaries of nature, should not be expected to yield as much per acre as do shrimp in intensively managed ponds. It has been reported that yields of 700 to 800 pounds per year can be expected in a one-crop year. This has to be compared with the 3000 pounds per acre realizable in a three-crop year in pond culture. The very low capital cost of embayment versus the high capital cost of pond culture for construction, must also be compared. Perhaps the single largest cost factor in pond culture is for the purchase of feed which the embayment system does not require. Predator control within the bay and fouling control on the nets may prove to be difficult problems to resolve.

Legal and other institutional restraints on use of public waters may be a serious, limiting factor in some parts of the world where embayment culture would otherwise be suitable. In Florida, recent legislation has been enacted to make possible and encourage such maricultural developments in the coastal waters. 


\section{CONCLUSION}

We are rapidly approaching the compatible confluence of marine biological scientific knowledge, economic validity and investment justification, and governmental awareness of the social benefits that can accrue from mariculture. I believe we can predict with a high level of certainty, the emergence within the next decade of a shrimp maricultural technology correlative in sophistication with the more advanced terrestrial animal husbandry industries.

\section{SUMMARY}

1. The continuing increase in demand for shrimps and prawns in the world markets, at a time when the basic understanding of the biology and ecology of Penaeid shrimps permits a more precise definition of the parameters of their culture, has provoked enlightened support of research and a considerable investment in field evaluation by several industry and government agents in the United States in an effort to establish a viable cultural enterprise.

2. Reproduction biology, spawning and larviculture, are reviewed here as they apply to the production of postlarvae of Penaeus duorarum, $P$. setiferus, and $P$. aztecus. Intensive culture in high-density postlarvae-stocked ponds, and extensive culture by postlarval seeding of natural embayments are compared and evaluated.

3. Management practices as exercised in the maintenance of high productivity conditions in the ponds, and embayments; feeding with appropriately formulated rations; and harvesting techniques are discussed for both cultural systems.

4. Potential growth rates, product yields and production costs can now be postulated, and the economic return on investment from a commercial venture can now be estimated.

\section{LITERATURE CITED}

Borja, P. C. \& Rasalan, S. B., 1969. A review of the culture of sugpo, Penaeus monodon Fabricius, in the Philippines. In: Proceedings of the World Scientific Conference on the biology and culture of shrimps and prawns, Mexico-City 1967. Ed. by M. N. Mistakidis. F.A.O. Fish. Rep. 57 (2), 111-123.

Broom, J. G., 1969. Pond culture of shrimp on Grand Terre Island, Louisiana 1962-1968. Proc. Gulf Caribb. Fish. Inst. 21.

Cоoк, H. L., 1970. A method of rearing penaeid shrimp larvae for experimental studies. In: Proceedings of the World Scientific Conference on the biology and culture of shrimps and prawns, Mexico-City 1967. Ed. by M. N. Mistakidis, F.A.O. Fish. Rep. 57 (3).

Fisheries of the United States, 1968. Publ. by the Fish and Wildlife Service, Bureau of Commercial Fisheries, U.S. Dpt of the Interior, Washington, D.C. 1969. (CHS No 5000).

Fugrnaga, M., 1942. Reproduction, development and rearing of Penaeus japonicus BATE. Jap. J. Zool. 10, 305-393.

- 1963. Culture of Kuruma shrimp (Penaeus japonicus). Curr. Aff. Bull. Indo-Pacif. Fish. Coun. 36, 10-11.

Holthuis, L. B. \& Rosa, H., 1965. Lists of species of shrimps and prawns of economic value. F.A.O. Fish. Biol. tech. Pap. 52. 
IdyLl, C. P. \& Sisson, R., 1965. Shrimp nursery: science farms the sea. Natn. geogr. Mag. $127(5), 636-659$.

- Tabb Durbin \& Yang Won Tack, 1968. Personal communication.

Kow, Thам Аң., 1969. Prawn culture in Singapore. In: Proceedings of the World Scientific Conference on the biology and culture of shrimps and prawns, Mexico-City 1967. Ed. by M. N. Mistakidis. F.A.O. Fish. Rep. 57 (2), 85-93.

Miyamura, M., 1969. Personal communication.

Oppenheimer, C., 1968. Personal communication.

Ryther, J. H. \& BARDACH, J. E., 1968. The status and potential of aquaculture. Vol. 1. Invertebrate and algae culture. Clearinghouse for Federal Scientific and Technical Information, Springfield, Va. (Design.: PB 177-767).

Webber, H. H., 1968. Mariculture. BioScience, Wash. 18 (10), 940-945.

WhEELER, R. S., 1966. Cultivation of shrimp in artificial ponds. Circ. Fish. Wildl. Serv., Wash. 246 (= A. Rep. biol. Lab., Galveston), 15-25.

Author's address: Dr. H. H. WebBer

Groton Associates, Inc.

Hollis Street

Groton, Mass. 01450, USA 